ISSN 2236-0859

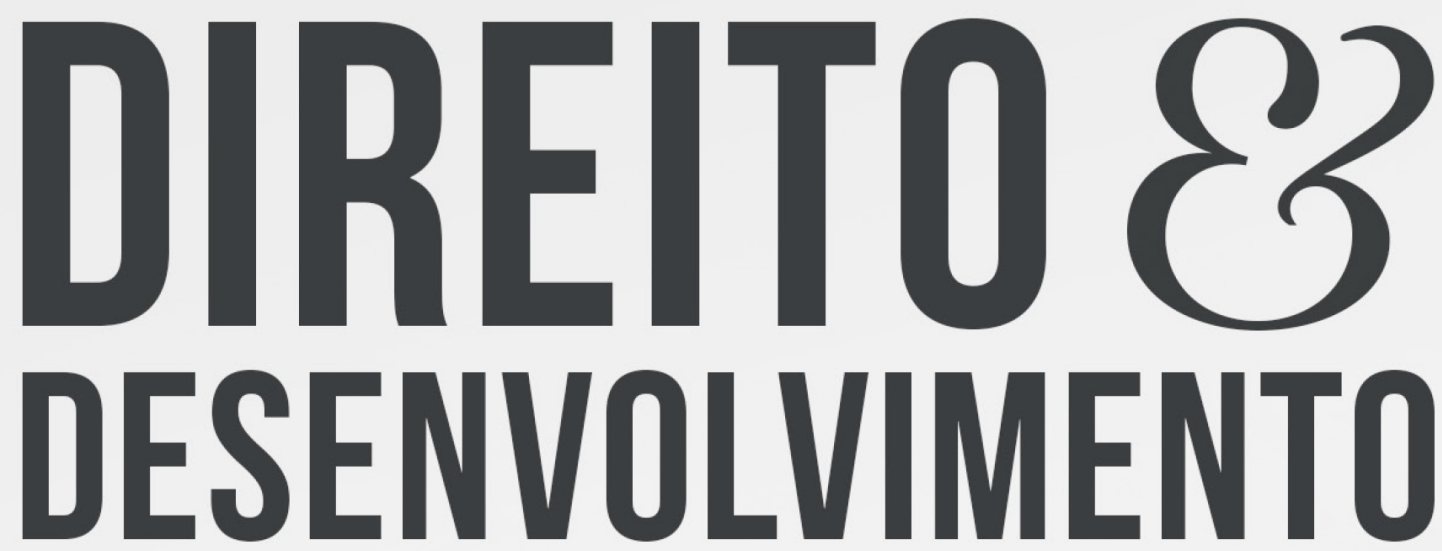

REVISTA DO PROGRAMA DE PÓS-GRADUAÇ̃̃O EM DIREITO MESTRADO EM DIREITO E DESENVOLVIMENTO SUSTENTÁVEL

FROM CRIMINAL PRINCIPIOLOGY TO THE RIGHT TO INTIMACY AS A CONSTITUTIONAL GUARANTEE

ROGÉRIO GRECO

ROMULO REMO PALITOT BRAGA 


\title{
FROM CRIMINAL PRINCIPIOLOGY TO THE RIGHT TO INTIMACY AS A CONSTITUTIONAL GUARANTEE
}

\section{DA PRINCIPIOLOGIA PENAL AO DIREITO À INTIMIDADE COMO GARANTIA CONSTITUCIONAL}

Recebido: 28/05/2021

Aprovado: 13/07/2021
Rogério Greco

Romulo Remo Palitot Braga ${ }^{2}$

\begin{abstract}
:
The current text presents an initial reflection on the importance of the Penal Law and its principles, expressed or implicit in a positivistic perspective. They should be understood as informants of all the juridical order with the capacity to ascertain the validity under constitutional class rules, occupying, in this way, a hierarchically superior place. It will also be considered, the bond between Penal Law and the recognition of the principle of the dignity of the human person, especially regarding the right to intimacy. The technique used to the bibliography
\end{abstract}

Keywords: Criminal principality. Dignity of the human person. Right to intimacy.

\section{RESUMO:}

O presente texto apresenta uma reflexão inicial sobre a importância do Direito Penal e seus princípios, expressos ou implícitos numa perspectiva positivista. Devem ser entendidos como informantes de todo o ordenamento jurídico com capacidade para averiguar a validade segundo as regras constitucionais de classe, ocupando, assim, um lugar hierarquicamente superior. Também será considerado, o vínculo entre o Direito Penal e o reconhecimento do princípio da dignidade da pessoa humana, especialmente no que se refere ao direito à intimidade. A técnica utilizada para a bibliografia

Palavras-chave: Principado criminoso. Dignidade da pessoa humana. Direito à intimidade.

\section{INTRODUCTION}

Criminal law is not simply a set of static norms ordered aesthetically, but is part of a complex and dynamic system fulfilling concrete functions within social relationships.

In the opinion of Mir Puig, Criminal Law consists in a form of social control sufficiently important that is monopolized by the State and, on the other hand, it constitutes one of the

1 Master in Criminal Sciences at UFMG ; PhD from the University of Burgos (Spain) ; Specialist in Theory of Crime from the Universidad de Salamanca (Spain); Professor of Criminal Law; Founding member of the Institute of Criminal Sciences (ICP) and the Brazilian Association of Teachers of Criminal Sciences; Attorney of Justice - MG. E-mail rogerio.greco@terra.com.br

$2 \mathrm{PhD}$ and Master in Criminal Law from the Universitat de València, Spain; Permanent professor at the Post-Graduate Program in Legal Sciences at the Federal University of Paraíba (UFPB) and at the Law and Development Program at UNIPE; President of the National Association of Criminal Law - ANACRIM-PB; Lawyer. E-mail romulo.palitot@uv.es 
fundamental portions of a state power that since the French Revolution has been considered necessary to be defined as clearly as possible as a guarantee for the citizen ${ }^{3}$.

Criminal law is the ultimate ratio of a state's legal system, constituting the instrument with the greatest power to achieve the objectives which are set and demanded by the political community ${ }^{4}$.

Despite the most varied discussions, we can consider the 18th century as a fundamental milestone for Criminal Law. Before it, the Criminal Law lived one of its worst moments, a period considered to be of darkness. With the arrival of the eighteenth century, with the prevalence of reason, a new century followed, considered now as the Century of Bright. From that time on, Criminal Law started to be considered as a true instrument of defense for the fundamental values of the community, where its purposes should only be used in considerably serious attacks on these values, in a limited and controlled form by the "rule of law"s.

As the Spanish professor Borja Jiménez ${ }^{6}$ rightly observes, until the enlightenment arrived, the criminal law was brutally used as a mechanism of oppression and submission of its vassals by the feudal lord. In contrast, political and religious interests of the church used the Criminal Law as an instrument for achieving certain purposes to some extent in much of the pejorative connotation of criminal science that moved through this turbulent and dark period.

Several defenders, during the Enlightenment period, stood up against the cruelty of the Criminal Law, including those of Montesquieu, Rousseau, Kant, Hegel, Beccaria ${ }^{7}$; in short, there were several thinkers who, in Europe, participated in a movement that had intended to provide radical changes in this branch of law.

Countless theories and principles applied to date arose during this period. The French Revolution of 1789 was one of the most important historical milestones for our discipline. The declaration of the rights of man and of the citizen is full of principles of a universal nature, which must be applied to every human being, regardless of their origin, race, sex, color, nationality, etc.

Many were the principles of criminal nature that originated in the Enlightenment period, principles which are considered as the foundation, i.e. they are considered as the foundation of the entire legislative structure.

\section{CONCEPTS AND NORMATIVE OF THE PRINCIPLES}

It is possible to highlight that the fundamental characteristic of the punitive power of the State is that it emanates from a Constitution, proper to the social and democratic State of Law, granting and limiting its extension, submitting them to the principles that are inspiring in the service of freedom, equality, justice and political pluralism ${ }^{8}$.

3 MIR PUIG, Santiago. Criminal outcome. General part. Barcelona: Reppertor. 1996. p. 5.

4 In this sense: BRAGA, Romulo Rhemo Palitot. Considerations and reflections on criminal law and criminal policy 1 . In: Revista da Ajuris - Magazine of the Association of Federal Judges of Rio Grande do Sul. Year XXXI. № 96. Porto Alegre. December 2004. P. 316; JAVIER MIRA. Javier. Functioning of the criminal law and form of State. In "Estudios Jurídicos en memoria del Profesor Dr. D. José Ramón Casabó Ruiz". Vol. II. Institut of Criminology. Universitat de València. Valencia. 1997. pp 393/417.

MARTINS, Fabiano Emídio de Lucena Martins; BRAGA, Romulo Rhemo Palitot, Crescente adoção de instrumentos de soft law na cooperação penal internacional, in: Revista Direito e Desenvolvimento, vol 4, núm. 02, 2013. P. 95

5 MUÑOZ CONDE, Francisco; GARCÍA ARÁN, Mercedes. Penal outcome. General part. Valencia: Tirant lo Blanch. 2004. p. 71. 6 BORJA JIMÉNEZ, Emiliano. Criminal policy course. Valencia: Tirant lo Blanch. 2003.

7 According to BORJA JIMÉNEZ, the doctrinal influence will arise with the work of Marques de Beccaria, thus establishing the first bases for the construction of a new humanitarian criminal law. Cfr.: BORJA JIMÉNEZ, Emiliano. The politicalcriminal conception of the Spanish Constitution. In: Present and Future of the Spanish Constitution. Law school of the Universitat de Valencia. Valencia: Tirant lo Blanch. 2005. pp. 135/151.

8 CABONELL.MATEU, Juan Carlos. Criminal outcome: concept and constitutional principles. Valencia: Tirant lo Blanch. 1999. pp. $106 / 107$ 
The word "principle", in the singular, indicates the beginning, the origin, the beginning, the primary cause. We can visualize and point out the principles for guiding the entire normative system, whether or not concretized. We affirm that, because the principles may be expressly provided in normative texts, such as the case with the principle of legality (Brazilian Federal Constitution, art. 5, XXXIX), or others that, although not positive, are mandatory, which is why which are called general principles of law 9.

Whether the principles are expressed or implied, concretized or not, its normative character is, simultaneously, understood. They are conceived as standards with a high level of generality and inform the entire legal system.

Importantly, according to Ana Paula de Barcellos, the seven criteria more used by doctrine leads to the distinction between principles and rules, namely:

(a) The content. The principles are closer to the idea of value and law. They form a demand for justice, equity or morality, while the rules have a diverse content and are not necessarily moral. Still regarding the content, Rodolfo L. Vigo even identifies certain principles, which he calls 'strong', with human rights.

(b) Origin and validity. The validity of the principles derives from their own content, whereas the rules come from other rules or from the principles. Thus, it is possible to identify the moment and the way in which a certain rule has become a legal norm, which will be useless in terms of principles.

(c) Historical commitment. The principles are for many (although not all), to a greater or lesser extent, universal, absolute, objective and permanent, whereas the rules are quite evident by the contingency and relativity of their contents, depending on the time and place.

(d) Ordering function. Principles have an explanatory and justifying function in relation to the rules. Like axioms and scientific laws, the principles synthesize a large amount of information from a sector or from the entire legal system, giving it unity and ordering.

(e) Linguistic structure. The principles are more abstract than the rules, in general, they do not describe the necessary conditions for their application and, therefore, they can be applied to an indeterminate number of situations. In relation to the rules, differently, it is possible to identify, with more or less work, your hypotheses of application.

(f) Interpretive effort required. The principles demand a much more intense argumentative activity, not only to clarify its meaning, but also to infer the solution it proposes for the case, whereas the rules demand only applicability, in the expression of Josef Esse, 'bureaucratic and technical '.

(g) Application. The rules are biunivocal, applying according to the 'all or nothing' model, popularized by Ronaldo Dworkin. That is, given its typical factual substrate, the rules only admit two kinds of situation: they are either valid and apply or they do not apply for invalid. Gradations are not allowed. As Robert Alexy records, contrary to the rules, the principles determine that something is accomplished to the greatest extent possible, admitting a more or less wide application according to the existing physical and legal possibilities ${ }^{10}$.

9 As explained by Olga Sánchez "the general principles of law allow, being the law faithful, to construct its application valiantly. At the time of legal interpretation, the norms are returned to the principles seeking their conformity with the set of material values recognized in the legal system, be it constitutional text or in the concrete regulation of the different legal institutions". In: MARTÍNEZ, Olga Sánchez. The principles of derecho and criminal dogmatics. Madrid: Dykinson. 2004. p. 46.

10 BARCELLOS, Ana Paula de. The legal effectiveness of constitutional principles. Rio de Janeiro: Renew. 2002. p. 47-51. 
Marcello Ciotola, pointing out the controversial confusion that occurs between norm and principle or, even between rule and principle, teaches, quoting Robert Alexy:

Robert Alexy notes that, although the distinction between rules and principles is not new, it prevents respect for confusion and controversy. In addition, a contrast that shows is made between norm and principle, and not between rule and principle. Questioning this stance, he states that rules and principles are species of the legal law genre:

"Both rules and principles are rules because they both say what should be. Both can be formulated with the help of the basic deontic expressions of the mandate, the permission and the prohibition. Principles, like rules, are reasons for concrete judgments of what should be, even if they are reasons of a very different kind. The distinction between rules and principles is thus a distinction between two types of norms" ${ }^{\prime 1}$

The principle is legally a norm, with comprehensive content, serving as an instrument for the integration, interpretation, knowledge and application of positive law ${ }^{12}$.

It is also worth mentioning the evolution related to the phases that the legality of the principles went through. Initially, the principles had a jusnaturalist character, followed by the positivist phase, and then, modernly, a post-positivist view was attributed to them.

Paulo Bonavides says that, in the jusnaturalist phase:

"The principles still inhabit the entire abstract sphere and its normativity, basically null and doubtful, contrasts with the recognition of its ethical-evaluative dimension of idea that inspires the postulates of justice"13.

In the second stage, considered positivist, the principles should be extracted from the post system standards in a given law, which serves as a source of rules subsidiary or expression of Gordillo Cañas cited by Paul Bonavides as a "safety valve" which "Guarantees the absolute rule of the law"14.

In the post-positivist phase, the Constitutions, following the lessons of Paulo Bonavides, "accentuate the axiological hegemony of the principles, converted into a normative pedestal on which the entire legal building of the new constitutional systems rests"15.

The principles, however, move in this last phase, to exercise primacy over the entire legal system, limiting, through the values selected by them, the legislative activity, only allowing, in the specific case of Criminal Law, for example, the creation normative that is not offensive to them.

As a result of this reasoning, we understand that the principles, given their character as a superior rule to the others existing in the legal system, serve as a guarantee to all citizens, in a Constitutional and Democratic State of Law, against the State's own attempts to defend itself in "omnipotent sir". Principles are, therefore, a protective shield of every citizen against state attacks. All rules owe you obedience, under penalty of being declared invalid.

Thus, concluding, at the same time, the principles, on a hierarchical scale, occupy the place of greatest prominence and importance, reflecting, necessarily, over the entire legal system.

${ }_{11}$ CIOTOLA, Marcello. General principles of law and constitutional principles - The principles of the 1988 constitution. P. 46. 12 In this sense: NUCCI, Guilherme de Souza. Constitutional principles of criminal law and criminal procedure. São Paulo: Revista dos Tribunais. 2010; SILVA, José Afonso da, positive constitutional law course. São Paulo: Malheiros. 1992.

13 BONAVIDES, Paulo. Constitutional law course. São Paulo: Malheiros. 1998. p. 232.

14 BONAVIDES, Paulo. Constitutional law course. Op. Cit. P. 234.

15 BONAVIDES, Paulo. Constitutional law course. Ibiden. P. 237. 


\section{THE PRINCIPLE OF HUMAN DIGNITY}

Pointing out the origin of the dignity of the human person, as a value to be respected by all, is not an easy task. However, looking at history, we can say that one of its strongest roots lies in Christianity. The idea, for example, of equality and respect between men, whether they are free or slaves, demonstrates that true Christianity that personified in the person of Jesus can be one of the foundations of this complex building of the dignity of the human person.

Taking a leap in the centuries, we will arrive at the Enlightenment period, the century of bright, where reason lit a fire, lighting the darkness that existed until that moment. The 17th and 18th centuries were of fundamental importance not only for effective recognition, but also for the consolidation of the dignity of the human person as a value to be respected by all.

Nevertheless, even recognizing its existence, conceptualizing the dignity of the human person remains an enormous challenge. This is because such a concept is found in the list of those considered vague and imprecise. It is a concept, in fact, that, since its origin, is in a process of construction. We cannot in any way build a wall for giving it precise contours, precisely because it is an open concept.

In many situations, only the analysis of the specific case will allow us to know whether there has been an effective violation of the dignity of the human person. For recognizing this concept, the historical and cultural diversity that reigns among peoples cannot be overlooked ${ }^{16}$. Thus, what in one culture can be conceived as a blatant violation of the rights to human dignity, in another it can be recognized as an honorable conduct.

Even the vilest, the most hateful man as cold and ruthless criminal is carrying that amount. We can adopt the proposed concept by Ingo Wolfgang Sarlet, which sought to condense some of the most used thoughts to define the concept of human dignity, saying that:

"The intrinsic and distinctive quality of each human being that deserves the same respect and consideration on the part of the State and the community, implying, in this sense, a complex of fundamental rights and duties that assure the person both against any and all acts of degrading and inhumane nature, as they will guarantee the minimum existential conditions for a healthy life, besides providing and promoting their active and co-responsible participation in the destinies of their own existence and of life in communion with other human beings" ${ }^{17}$.

The dignity of the human person, in the words of Paulo Bonavides, ceased to be exclusively a conceptual manifestation of that natural right, whose essence was sought either in divine reason or in human reason. As the thinkers of the classical periods professed in their lessons of theology and philosophy and medieval, in order to become, finally, an autonomous proposition, of the highest axiological content, irrevocably tied to the constitutional realization of fundamental rights ${ }^{18}$.

Although difficult to translate, we can endeavor to try to build a concept of the dignity of the person, understood as a quality that integrates the human condition itself, being, in many situations, still considered as unavoidable and inalienable. It is something inherent to the human being, a value that cannot be suppressed, due to its very nature.

16 On cultural diversity: BORJA JIMÉNEZ, Emiliano. Cultural Diversity: conflict and conflict . Valencia: Tirant lo Blanch. 2006. 17 SARLET, Ingo Wolfgang. Human dignity and fundamental rights. Porto Alegre: Lawyer's Bookstore. 2001. p. 60.

18 BONAVIDES, Paulo. Constitutional theory of participatory democracy. São Paulo: Malheiros. 2003. p. 231. 


\subsection{The normative conception of human dignity}

Once the dignity of the person is recognized as an inherent value of every human being, its normative embodiment was an important step.

The twentieth century, especially after the atrocities committed by Nazism ${ }^{19}$, witnessed the growth of the human principle of the dignity, as well as its formalization in the texts of the constitutions, especially the democratic ones.

The principle of the dignity of the human person serves as the guiding principle of many others, as it does with the principle of individualization of punishment, personal responsibility, guilt, proportionality, etc., which seek its foundation of validity.

The modern Constitutions expressly adopt the principle of human dignity, being one of the foundations of the Federative Republic of Brazil, as determined by our Political Charter of October 5,1988 , in its art. 1st, $\mathrm{III}^{20}$.

It is clear, therefore, the concern of the constituent legislator to grant a normative status to the principle of human dignity, understanding it as one of the foundations of the Democratic Rule of Law.

As a constitutional principle, the dignity of the human person should be understood as a norm of a higher hierarchy, intended to guide the entire system with regard to legislative creation, as well as to assess the validity of the norms that are inferior to him. Thus, for example, the infraconstitutional legislator would be prohibited from creating incriminating criminal types that would violate the dignity of the human person, and the combination of cruel penalties, or of an afflictive nature, such as whips, is prohibited.

In our country, after a slow evolution, the Federal Constitution, aiming to protect the rights of the citizen, prohibited the combination of a series of penalties ${ }^{21}$, as it understood that all of them, in a broad sense, offended the dignity of the human person, in addition to fleeing, in some cases its preventive function. Therefore, item XLVII of art. 5 of the Federal Constitution expressly determines that there will be no death penalty a), except in cases of declared war, under the terms of its art. 84, XIX; b) perpetual character; c) forced labor; d) banishment and e) cruelty ${ }^{22}$. Similarly, would be prohibited the act of torture as a mean to obtain the confession from an indicted/ accused (by greater than gravity was, in theory, the criminal offense committed).

So, we can say with Lucretius Rebollo Delgado that we have to take into account that human dignity constituted not only the guarantee that the person will not be object of offenses or humiliation, but also introduces a positive affirmation of full development of the personality of each individual ${ }^{23}$ ". In addition, the invalidity of any legal device that contradicts this basic value, inherent to every human being, must be declared.

On the other hand, even if the dignity of the human person had not been elevated to the status of an expressed principle, no one would doubt its quality as an implicit principle ${ }^{24}$,

\footnotetext{
19 Historical records demonstrate strong authoritarianism, such as the "Kiel School”. Vives Antón y Cobo Del Rosal, quoting Quintano Ripolles, calls the followers of this "School" "Nazi jurists". Cf.: VIVES ANTÓN, Thomas; COBO DEL ROSAL, Manuel. Derecho penal - general part. Valencia: Tirant it Blanch. 1999. p. 324.

20 In this sense: CARVALHO, Pedro Armando Egydio de. The penal system and human dignity. In: IBCCRIM Bulletin. Sao Paulo. No. 70 / Ed. esp. September 1998. pp 02/o3.

21 "It is also true that the retributive nature of the penalty, as a form of social example, should not be overlooked. However, it must be mitigated by the need for social reintegration of the condemned with respect for the dignity of the human person and, even because, in our country, in times of peace, there are no perpetual or capital punishment, from which the certainty of the return of the condemned to the social bosom, the situation for which he must be prepared in the best possible way" (TRF - $3^{\mathrm{a}}$ - HC $26.55^{2-S P}$, $5^{\mathrm{a}}$ T. Rel. Ramza Tartuce, August 20, 2008).

22 GRECO, Rogério, Criminal Law Course. General part. Niterói: Impetus, 2011, p. 469.

23 DELGADO, Lucrecio Rebollo. Fundamental rights and data protection. Madrid: Dykinson, 2004. p. 18.

24 The principles, even if implicit, must have full normative applicability, prevailing, even over express rules. Cfr.: GUERRA, Gustavo Rabay . Constitutional procedural law. Recife: Our bookshop. 2005. p. 37.
} 
arising from the Democratic State of Law itself, capable, nonetheless, of assessing the validity of lower level.

\subsection{Relativizing the principle of human dignity}

The dignity of the human person, according to the major doctrine, does not have an absolute character, we must, in certain situations, work with other principles that will serve as interpretation tools, carrying out the so called weighting or interests, which will result in the prevalence of one over the other.

Dignity, as an individual value of each human being, must be assessed and weighed in each specific case. We must not forget, however, what is an essential core of the dignity of the human person, which can never be diminished. Thus, it is one thing to allow someone, who has committed a serious criminal offense, to be deprived of their liberty by the State itself, charged with ultimately protecting legal assets. It is another thing to allow that same person condemned with deprivation of liberty to serve his sentence in a degrading place affecting his personality; that he will be tortured by government agents in order to extract some confession from him; that his relatives are prevented from visiting; who does not have a re-socializing occupation in prison, etc. His dignity must be preserved, since the State was only allowed to deprive him of his freedom, however, the other rights that affect his dignity as a person, are protected.

Dignity, on the other hand, may be weighed against the own interests of the person who owns it, and who thinks about having it, in a given situation, and the State can act, even if coercively, in order to preserve it, even against the expressed wish of its holder.

However, it is not the easiest task to conclude when we are facing an offense against the dignity of the human person. Even against the expressed will of the person to whom we intend to defend ourselves, or when we will be, due to this balance of interests, facing a right person, even if, in the opinion of third parties, it is offensive to their dignity.

\section{PERSONALITY RIGHTS AS INTEGRAL TO THE DIGNITY OF THE HUMAN PERSON}

Personality can be pointed out as a direct result from the principle of the dignity of the human person, meaning, briefly, the ability of every human being to have its rights respected and to assume obligations, or, according to the precise lessons of Pablo Stolze Gagliano and Rodolfo Pamplona Filho:

\footnotetext{
"Personality rights are conceptualized as those whose object is the physical, psychological and moral attributes of the person in himself and in his social projections.

The idea to guide the discipline of personality rights is from an individual's offbalance sheet sphere, in which the subject has admittedly tutored by the legal order an indeterminate series of pecuniary non-reducible values, such as life, physical integrity, intimacy, honor, among others" 25 .
}

It is a right inherent in every human being.

There are rights that are born with every human being, regardless of their origin, race, sex, color, religion, similar to what occurs with the right to life, sexual freedom, physical integrity, honor, intimacy etc., and that cannot be removed from it.

25 GAGLIANO, Pablo Stolze; Pamplona Filho, Rodolfo. New civil law course - general part, São Paulo: Saraiva. 2011. p. 150. 
However, there are no absolute rights, even those considered very personal. As an example, let us mention the right that everybody has freedom. In spite of that, if the agent comes to practice a fact liable to a sentence of deprivation of liberty, that right will cease in the specific case. Thus, we can only consider the rights to personality as absolute in the sense of being opposable erga omnes, and not with regard to their intangibility.

Although we have positioned ourselves on the side that the rights inherent to personality are innate, that is, they are born bound to every human being and are antecedents to any normative disposition, being, moreover, considered as natural rights, such a position is not peaceful.

In the opposite direction to the Jusnaturalist School of personality rights, there is the position understood as positivist, which assumes that there will only be a right when it is formally recognized by the State, through its legal statutes. New situations emerge, new conflicts will occur, causing the legislator to awaken to the existence of new rights, which can be considered as very personal, thus being part of the personality of the human being. It is the law, according to this current, that is in charge of recognizing and protecting rights that have been selected through a political criteria, which has changed over the years.

Despite the strength of positivist reasoning, especially with regard to the recognition of new personality rights which are emerging according to the evolution of society, there are certain groups of rights that cannot be attributed to formal recognition. The law, for example, as we have already said, the right to life, personal integrity, honor, intimacy, etc.

Personality rights have certain characteristics that are peculiar to them, which distinguish them from others. In addition to being considered absolute, in the sense that they are opposable to erga omnes, personality rights enjoy the characteristics of: generality, offbalance, non-transferability, unavailability, imprescriptibility, impenetrability and life tenure.

It appears that according to their nature, as well as the characteristics that are peculiar to them, the rights about personality are part of the role pertaining the dignity of the human being.

\section{RIGHT TO PRIVACY AS PART OF THE CATEGORY OF RIGHTS TO PERSONALITY}

The right to privacy is one of the most subtle and also the most difficult personality rights to be delimited or protected by criminal law.

Nowadays, it is no longer argued that the right to privacy is part of the list of so-called personality rights, which, consequently, concern the dignity of the human person.

However, although belonging to the category of very personal rights and enjoying, at first sight, all the characteristics that are inherent to it, it is worth emphasizing, generality, extra-patrimonialism, non-transferability, unenforceability, imprescriptibility, unenforceability and life tenure, precisely, talking about a person's privacy it is not an easy task.

This is because the concept of intimacy varies according to customs, place, creation, values according to the society in which the subject is inserted, in short, pointing out the right to intimacy and, on the other hand, their violations, which can be punished in different degrees, such as civil and penal, each detail deserves a thorough analysis.

Take, for example, what still occurs in many indigenous tribes, still present in Brazil, where the members that make up the group have the habit of walking completely naked, from children to the elderly. Nudity, for them, is not a matter of intimacy, as it is available for everyone to see. Whoever is a member or not, who joins that group, will witness the nakedness of all. 
We all bring with us a part of our personality that we do not want to be revealed, or, when revealed to a few people, we do not accept the breach of trust placed, and we reject its undue disclosure.

The right to privacy is, figuratively, a room, where the door can only be opened from the inside. Any attempt to enter will result in a break-in, an undue violation, deserving of punishment.

\section{THE FUNDAMENTAL RIGHT TO PRIVACY AS A RESULT OF THE PRINCIPLE OF HUMAN DIGNITY AND ITS CONSTITUTIONAL FOUNDATION}

From what we have seen so far, we can state that the principle of human dignity, whether or not express constitutional provision, will serve as the foundation of the entire regulatory system. In addition, it has been understood that the principle of human dignity is the source which emanates fundamental rights.

The most modern constitutions, such as the Brazilian and Spanish, not only predict the principle of human dignity, but also rights that are altogether with the rights to privacy.

Nevertheless, what does the right to intimacy means?

Conceptualizing the right to intimacy is not an easy task. It is extremely difficult, in fact, not only conceptualize what may be right to privacy, but also traces its exact contours, making a distinction between public and private. According to Ekmekdjian, intimacy is the faculty where each person owns a circle: private or unremitting stronghold of individual freedom, which cannot be invaded by third parties, whether private or the State itself, through any type of interference, which can take several symbols ${ }^{26}$.

We can list three theories disputing the treatment for the right to privacy. The first of them, called objective theory, adopts the so-called theory of circles, of German law, where we can represent, figuratively, several concentric circles, with the most intimate, reserved in the center; around, family intimacy; and, finally, on its outer face, the area for the public sphere. Obviously, this definition is not absolute, but a mere theoretical representation.

The second theory, recognized as subjective, as the denomination itself is suggesting, understands that only the person, and no one else, can determine what is or is not intimate, that is, he is the only who must determine the limits between the private and the public.

Modernly, the so-called mosaic theory emerged, as a need to protect the individual's intimacy "in the face of threats that, the new technological devices and in particular the computer science are harming. It was formulated by Madrid Conesa who believes that the 'theory of spheres is not valid, given that today the concepts of public and private are relative, as there are data that a priori are irrelevant from the point of view of the right to privacy. However, if they are united to each other can configure the thoughts of any individual, such as the small stones that form a mosaic, which in themselves do not say anything, but when together they can form meaningful sets" ${ }^{27}$.

We can now understand that the real concept of the right to privacy is not absolute in nature, it varies from person to person, from society to society, from culture to culture, from time to time. Thus, what may constitute a violation of the right to privacy in a society, will no longer be in another ${ }^{28}$. Therefore, this privacy, what humans want to preserve and do not want

26 EKMEKDJIAN, Miguel Ángel. Elemental Treaty of Constitutional Derecho. Barcelona: Paidós. 1993. 27 DELGADO, Lucrecio Rebollo. Derechos y fundamentales proteción de datos, Op. cit. 38-39.

28 Canotilho cites the following case: "An individual, female, is applying for a job in a private company, having been selected first, after the qualification tests and the interview. However, before the contract was signed, the company demanded a pregnancy test, which she refused because it was an attack on the fundamental right to the privacy of private and family life . Cfr : CANOTILHO, José Joaquim Gomes. Fundamental rights studies . São Paulo: Coimbra Editora and Revista dos Tribunais. 2008 . p. 70. 
to be known by others, will have a relative nature that cannot be applied to general concepts or ordained ones.

Surely, however, we can say that individuals have their special reservation. In each human being there is a safe, where their most precious values are kept, protected, unavailable for the knowledge of others.

Thus, although its definition is complex, it does not have the intention of exhausting the debate, we can realize that the right to intimacy is a portion, inherent to our right of personality, which belongs solely to us, and which should, according to our will , be subtracted from public knowledge ${ }^{29}$.

\section{RIGHT TO PRIVACY OF PUBLIC PERSONS}

In some situations, as for public persons, the right to privacy is limited. Public life implies a certain permission to the public to know more details about that person who decides to expose himself or herself, through his activities. However, as much as a limitation of the right to privacy is recognized, this limitation does not matter, as it can be seen, in its total annihilation. A precise lesson of Paulo José da Costa Júnior:

\footnotetext{
"Notorious people can lose, due to the peculiar way of life or profession by virtue of which they have become personalities of public interest, to a certain extent, the right to privacy. But they will have to preserve a part of the intimacy preserved, to which only those who are allowed to penetrate will have access. A sphere of intimacy, even a reduced one, will guarantee notorious personalities, where they can freely excuse themselves, without being accounted by anyone, sheltered from the curiosity of others. Although it is precisely this sphere, which is to be removed from popular curiosity, to leave it enclosed in the walls of the home or in the tabernacle of domestic intimacy, the one that most appeals to the general public. It is like the revenge of a mediocre man - someone has already proclaimed -, who wants to know how the one who reached a greatness that he was not able to achieve lives and how behaves in intimacy"30.
}

Not only can the disclosure of unpublished facts affect people's right to privacy. Often, even the facts already known by the public, are lately disclosed, or mentioned a second time, recalling past events, it can damage the right to privacy. In these cases, we speak about the so-called right to be forgotten.

\section{AVAILABILITY OF THE RIGHT TO PRIVACY AND CONSENT OF THE VICTIM}

The right to intimacy can only be recognized as absolute in the sense of being opposable erga omnes. With this, we want to affirm that, only in the specific case will be able to tell us if there will be the possibility or not of its disposition by the holder of this right.

Thus, in many cases, it will be possible for the subject to have his privacy, turning it public, the knowledge of all. Consequently, that part that we all understood as reserved, like our sexual freedom, may be available for everybody. Consider the case of "pornographic film actor". His intimacy is fully on display in those scenes. However, in such cases, it has been understood that if the right holder is larger and capable person, consent will be valid in order to allow their intimacy being noticed.

29 Cfr.: SILVA, Edson Ferreira da. Right to privacy. São Paulo: Juarez de Oliveira, 2003. p. 51.

30 COSTA JÚNIOR, Paulo José. Aggressions against intimacy. São Paulo: Malheiros. 1997. p. 28. 
It is also not uncommon for someone letting a writer narrate his biography by making available to the public what he considered most reserved.

Therefore, we understand that when it comes to intimacy, this right may be considered available as long as the holder is a person of legal age ${ }^{31}$, and has the capacity to consent (which means not carrying any mental illness that prevents you from knowing nature of the behavior practiced by him etc).

Any addiction will become also invalid consent.

Another feature that should be emphasized is that consent, which is a personal right, can be revoked at any time. It does not matter if the subject initially consented. If there is repentance, such consent may be revoked. So, imagine the hypothesis where a writer had received authorization from a certain person to publish his biography. To this end, they spent months together, so that the author of the work could know all the necessary details for the publication of the book. Repentant, and concerned with the repercussion of the facts, the subject who would have exposed his biography prevents the book from being published. In this case, the consent is valid in order to effectively prevent the publication of the work. However, this does not rule out the possibility that the subject, holder of the right to privacy, will have to indemnify the person who has lost months working, in order to make some profit from selling the book.

Hence, it will be possible for the right holder to consent so that their privacy is exposed to the public, but they can, however, regret it at any time. Besides that, it is not possible to consider any forced execution to comply with the object for consent previously given, which does not prevent anybody from being held civilly responsible for any harm caused.

\section{FINAL CONSIDERATIONS}

Due to the dimension of the subject that has been explained, many other issues could have been addressed or even deepened, but it would be too long. Therefore, we seek to highlight its main aspects.

Among the principles considered as the foundation of the democratic rule of law, we can highlight the principle of dignity of the person, which constitutes, according to the lessons of Lucrecio Rebollo Delgado, "no sólo la garantia negativa de que la persona no va a ser obejto de ofensas o humillaciones, sino que entraria también la afirmación positiva de pleno desarollo de la personalidad de cada individuo"32.

The right to personality is a natural consequence of the adoption of the principle of the dignity of the person, enjoying the characteristics of generality, extra-patrimoniality, nontransferability, unenforceability, imprescriptibility, impenetrability and life tenure.

Although understood as unavoidable or unavailable, this characteristic is not absolute, with the possibility of exceptions dictated not only by law, but also by customs, social and moral values existing at a given time.

One of the facets related to the right to personality is precisely the right to privacy. Although it is difficult to define the scope of this right to privacy, there is a need to draw boundaries between the public and the private. Over the years, several theories have emerged for this purpose, including the following: a) objective theory, also known as theory of spheres; b) subjective theory; and c) mosaic theory.

31 Legal age is understood to be that of a civil nature, as is the case in Brazil with those over 18 years of age. 32 DELGADO, Lucrecio Rebollo. Fundamental rights and data protection. Op. cit. P. 18. 
The offense against the right to privacy may generate sanctions of both a civil and a criminal nature, regardless, in many situations, of actual damage to the person who has had his or her privacy violated.

Although it is seen as a personality right, the right to privacy may be considered available, requiring, therefore, the consent of the holder of that right.

\section{REFERENCES}

BARCELLOS, Ana Paula de. The legal effectiveness of constitutional principles. Rio de Janeiro: Renew. 2002;

BONAVIDES, Paulo. Constitutional law course. São Paulo: Malheiros. 1998;

BONAVIDES, Paulo. Constitutional theory of participatory democracy. São Paulo: Malheiros. 2003;

BIMJA JIMÉNEZ. Diversidad Culture: conflict y derecho. Valencia: Tirant lo Blanch. 2006

BIMJA JIMÉNEZ. Criminal policy course. Valencia: Tirant lo Blanch. 2003;

BIMJA JIMÉNEZ. La Concepcion political-criminal of la Constitución española. In: y Present Future la Constitución Española. Faculty of Derecho de la Universitat de València. Valencia: Tirant lo Blanch, 2005.

BRAGA, Romulo Rhemo Palitot. Considerations and reflections on criminal law and criminal policy I. In: Revista da Ajuris - Magazine of the Association of Federal Judges of Rio Grande do Sul. Year XXXI. № 96. Porto Alegre. December 2004;

CABONELL MATEU, Juan Carlos. Criminal outcome: concept and constitutional principles. Valencia: Tirant lo Blanch. 1999;

CANOTILHO, José Joaquim Gomes. Fundamental rights studies. São Paulo: Coimbra Editora and Revista dos Tribunais. 2008;

CARVALHO, Pedro Armando Egydio de. The penal system and human dignity. In: IBCCRIM Bulletin. Sao Paulo. No. 70 / Ed. esp. September 1998;

CIOTOLA, Marcello. General principles of law and constitutional principles - The principles of the 1988 constitution;

COSTA JÚNIOR, Paulo José. Aggression against intimacy. São Paulo: Malheiros. 1997;

DELGADO, Lucrecio Rebollo. Derechos fundamentales y protección of datos. Madrid: Dykinson, 2004;

EKMEKDJIAN, Miguel Ángel. Elemental Treaty of Constitutional Derecho. Barcelona: Paidós. 1993; 
GAGLIANO, Pablo Stolze; Pamplona Filho, Rodolfo. New civil law course - general part. São Paulo: Saraiva. 2011.

GRECO, Rogério. Criminal law course. General part. Niterói: Impetus, 2011;

GUERRA, Gustavo Rabay. Constitutional procedural law. Recife: Our bookshop. 2005;

JAVIER MIRA, Javier. Función del derecho penal y form of state. In "Estudios Jurídicos en memoria del Profesor Dr. D. José Ramón Casabó Ruiz ”. Vol. II. Institut de Criminologia. Universitat de València. Valence. 1997;

SÁNCHEZ MARTIINEZ, Olga Sánchez. Los principles del derecho y la criminal dogmatic. Madrid: Dykinson. 2004.

MARTINS, Fabiano Emídio de Lucena Martins; BRAGA, Romulo Rhemo Palitot, Crescente adoção de instrumentos de soft law na cooperação penal internacional, in: Revista Direito e Desenvolvimento, vol 4, núm. 02, 2013.

MIR PUIG, Santiago. Criminal outcome. General part. Barcelona: Reppertor. 1996;

MUÑOZ CONDE, Francisco; GARCÍA ARÁN, Mercedes. Penal outcome. General part. Valencia: Tirant lo Blanch. 2004;

NUCCI, Guilherme de Souza. Constitutional principles of criminal law and criminal procedure. São Paulo: Revista dos Tribunais. 2010;

PEIXINHO, Manoel Messias. The interpretation of the constitution and the fundamental principles. Rio de Janeiro: Lumen Juris, 20oo;

SARLET, Ingo Wolfgang. Human dignity and fundamental rights. Porto Alegre: Lawyer's Bookstore. 2001.

SILVA, Edson Ferreira da. Right to privacy. São Paulo: Juarez de Oliveira, 2003;

SILVA, José Afonso da. Positive constitutional law course. São Paulo: Malheiros. 1992;

VIVES ANTÓN, Tomás; COBO DEL ROSAL, Manuel. Criminal outcome - general part. Valencia: Tirant lo Blanch. 1999. 